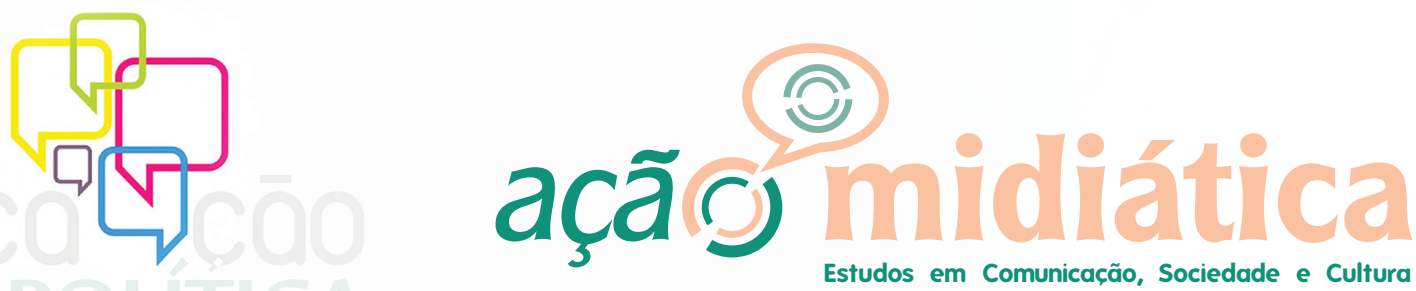

Estudos em Comunicação, Sociedade e Cultura

N. 6 | Ano 2013

Universidade Federal do Paraná I Programa de Pós-Graduação em Comunicação

\title{
Mídias Digitais e suas potencialidades nos tempos contemporâneos: estudo de caso "Mídia Ninja"1
}

Digital Media and its potential in contemporary times: case study "Midia Ninja"

Digital Media y su potencial en la época contemporánea: caso de estudio "Mídia Ninja"

\section{RESUMO}

Ofelia Elisa Torres MORALES ${ }^{2}$

Carlos Alberto de SOUZA ${ }^{3}$

Paula Melani ROCHA ${ }^{4}$

Este texto traz aproximação preliminar em relação a indagações e questionamentos sobre as possibilidades oportunizadas pelas redes sociais digitais e o jornalismo móvel. A partir de algumas exemplificações como o caso da "Mídia Ninja", mídia digital alternativa com visibilidade potencializada nas manifestações do Movimento "Vem Pra Rua", mostra-se a necessidade de compreender esses fenômenos midiáticos, principalmente na sociedade contemporânea, sob a ótica da juventude e da cidadania, assim como suas potencialidades na construção do conhecimento colaborativo e compartilhamento de informações e opiniões. A análise envolveu pesquisa exploratória, bibliográfica, estudo de caso e análise de imagem.

Palavras-chave: Redes Sociais Digitais; Juventude; Jornalismo Móvel; Mídia Ninja.

\begin{abstract}
This text brings preliminary approach in relation to inquiries and questions about the possibilities opportunized by digital social networks and mobile journalism. From some exemplifications as the case of "Mídia Ninja", digital media alternative enhanced visibility in the manifestations of Movement "Vem pra Rua", shows the need to understand these media phenomena, especially in contemporary society, from the perspective of youth and citizenship, as well as their potential in collaborative knowledge building and sharing of information and opinions. The analysis involved exploratory research, bibliography, case study and image analysis.
\end{abstract}

Keywords: Digital social networks; youth, mobile journalism, Midia Ninja.

\section{RESUMEN}

Este texto trae aproximación inicial en relación a las indagaciones y cuestionamientos sobre las posibilidades ofrecidas por las redes sociales digitales y el periodismo móbil. A partir de algunas ejemplificaciones como el caso del "Mídia Ninja", media digital alternativa con visibilidad potencializada en las manifestaciones del Movimiento "Vem Pra Rua", se muestra la necesidad de comprender esos fenómenos mediáticos, principalmente en la sociedad contemporánea, bajo la óptica de la juventud y de la ciudadanía, así como sus potencialidades en la construcción del conocimiento

1 Trabalho apresentado à sexta edição da Revista Ação Midiática - Estudos em Comunicação, Sociedade e Cultura, publicação ligada ao Programa de Pós-Graduação em Comunicação, da Universidade Federal do Paraná.

2 Doutora em Jornalismo pela Escola de Comunicações e Artes da Universidade de São Paulo (ECA-USP). Professora Adjunta do Curso de Jornalismo da Universidade Estadual de Ponta Grossa (UEPG). Contato: ofeliatm@gmail.com

3 Doutor em Ciências Humanas pela Universidade Federal de Santa Catarina (UFSC). Professor Adjunto do Curso de Jornalismo da Universidade Estadual de Ponta Grossa (UEPG), coordenador do Grupo de Pesquisa Fotojornalismo, Imagem e Tecnologia. Contato: carlossouza2013@hotmail.com

4 Professora Doutora dos cursos de mestrado em Jornalismo e da graduação em Jornalismo da Universidade Estadual de Ponta Grossa (UEPG). Professora-colaboradora do LabJor/UNICAMP. Contato: pmrocha@uepg.br 


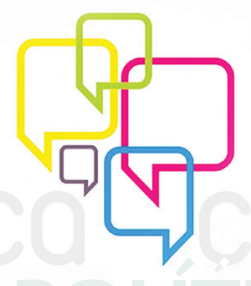

ação mididiática

N. 6 | Ano 2013

Universidade Federal do Paraná | Programa de Pós-Graduação em Comunicação

colaborativo y compartir informaciones y opiniones. El análisis envolvió investigación exploradora, bibliográfica, estudio de caso y análisis de imagen.

Palabras-clave: Redes Sociales Digitales; Juventud; Periodismo Móbil; Mídia Ninja.

\section{Paradigmas de pesquisa: aproximações qualitativas}

Para melhor aproximação ao objeto de estudo foi necessário propor uma estratégia de pesquisa abrangente que pudesse captar na sua totalidade, um fenômeno significativo e complexo como a inter-relação em 'tempo real' entre jovens favorecida pelas redes sociais, dispositivos móveis e meios de comunicação (televisão, rádio, impressos).

O texto pretende, como movimento inicial, realizar uma análise do referencial teórico relacionado à temática, visando identificar vasos comunicantes do jornalismo contemporâneo e a sociedade, mergulhando na análise do jornalismo como formador de opinião na construção da cidadania, e a representação dos jovens na mídia, nos tempos contemporâneos. Para isso, foi desenvolvida pesquisa exploratória, sobre as manifestações dos jovens, relacionadas ao "Movimento Passe Livre", o "Vem Pra Rua", dada sua relevância social, que tomou proporções jamais imaginadas por meio das redes sociais. Nesse espaço digital, jovens de todo o Brasil criaram uma 'verdadeira comunidade' para defender interesses da coletividade e mostrar a insatisfação com o poder político nos municípios, estados e federação.

Seguindo observações referidas por Rodrigues (2007, p. 28), a pesquisa exploratória é um tipo de pesquisa:

[...] cuja finalidade é descortinar o tema, reunir informações gerais a respeito do objeto. [...] A pesquisa exploratória destina-se a esclarecer do que se trata, a reconhecer a natureza do fenômeno, a situá-lo no tempo e no espaço, a inventariar suas manifestações variadas, seus elementos constitutivos ou as contiguidades presentes à sua manifestação.

Conforme o procedimento técnico, esta pesquisa é bibliográfica, documental e, também, um estudo de caso, já que na parte final deste trabalho é feita uma análise do "Mídia Ninja", hospedado no Facebook. Andrade (2005) define a pesquisa bibliográfica e a documental, como o uso de fontes secundárias e fontes primárias, respectivamente. Esse texto objetiva focalizar a convergência midiática, das redes sociais digitais e dos dispositivos móveis, os quais, durante os meses de junho e julho de 2013, reverberaram a questão das manifestações do "Vem pra Rua".

A abordagem é qualitativa, seguindo a linha de pensamento de Santaella (2001), conforme a qual este tipo de pesquisa "acabou por desenvolver autonomia própria, podendo 

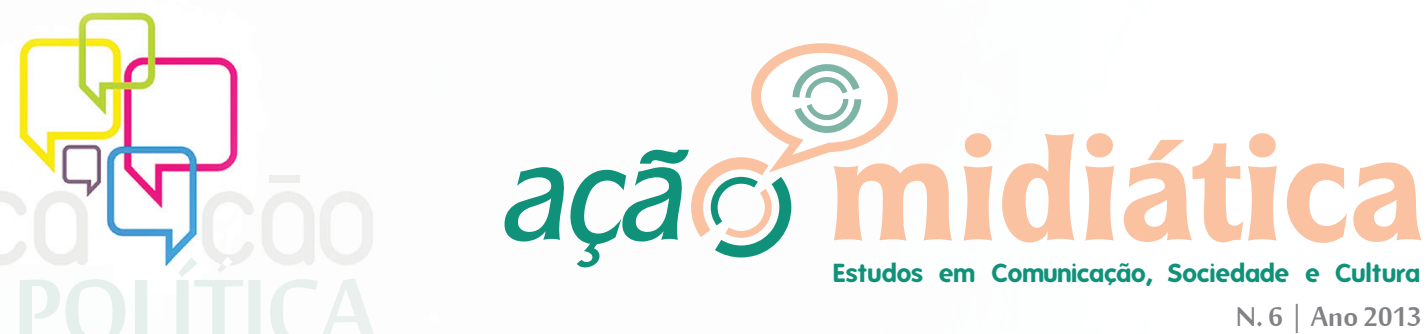

Universidade Federal do Paraná | Programa de Pós-Graduação em Comunicação

se referir a todas as pesquisas que privilegiam a interpretação dos dados, em lugar de sua mensuração." Por isso, a escolha pela abordagem é mais interpretativa, no sentido de compreender as diversas faces do objeto proposto neste texto.

\section{Pontos de partida: mídias digitais, redes e mobilidades}

O relacionamento dos jovens e adolescentes, em tempos de mobilidade, interatividade e relacionamento nas redes sociais digitais enfatizam os desafios comunicacionais contemporâneos. Inicialmente, procura-se compreender a relevância do jornalismo na construção da cidadania, a partir do estudo das mídias comunicacionais e seu relacionamento com jovens e adolescentes em contextos contemporâneos. Isto é, entender a relevância do jornalismo como forma de compreensão da realidade e como forma de conhecimento, a partir de sua dimensão ética, técnica e estética, na construção da cidadania, em tempos digitais e de mobilidade.

[...] nós não vemos [...] a realidade como 'ela'é, mas como são nossas linguagens.

E nossas linguagens são nossos meios de comunicação. Nossos meios de comunicação são nossas metáforas. Nossas metáforas criam o conteúdo de nossa cultura. (POSTMAN apud CASTELLS, 2002, p. 414)

Pretende-se discutir esse panorama a partir das representações dos jovens e da cidadania, num cenário midiático em transformação, focalizando principalmente as potencialidades dos dispositivos móveis inseridos nas redes sociais digitais. Um fato marcante que expressa flutuantes delimitações a respeito da apropriação pelos jovens das mídias ocorreu nos meses de junho e julho de 2013, com o Movimento Passe Livre, "Vem Pra Rua", movimento que frutificou nas redes sociais digitais e se retroalimentou nas ruas de todo o país.

Por um lado, esse movimento de revolta social, que surgiu de forma efervescente, prioritariamente, a partir das redes sociais digitais, saiu às ruas não somente nas principais cidades-eixo, como São Paulo e Rio de Janeiro, mas ampliou-se em todo o Brasil. Por outro lado, esse tema foi agendado na imprensa brasileira e internacional, assim como também houve um contra-agendamento na imprensa brasileira, a partir de experiências nas redes sociais como mídias alternativas.

A teoria do agendamento foi formulada pelos autores americanos Maxwell E. McCombs e Donald L. Shaw ao analisarem a cobertura midiática da campanha eleitoral de Nixon à presidência dos EUA em 1968 e, posteriormente as eleições, em 1972. Entre as conclusões apontadas nesses estudos, é que o público sofre influência de determinado veículo de comunicação, a médio e longo prazo, levando-o a pensar sobre determinados temas que, de acordo com Hohlfeldt (1997), de outro modo, não chegariam ao seu conhecimento e, muito menos, tornar-se-iam 


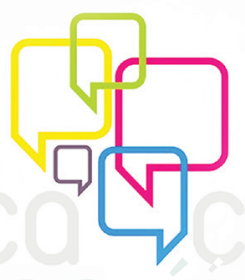

açãô I) Midiática

N. 6 | Ano 2013

Universidade Federal do Paraná | Programa de Pós-Graduação em Comunicação

temas da agenda social. Ou seja, a mídia provocou um impacto e influenciou não apenas o leitor, mas também outros candidatos que inseriram determinados temas na sua agenda social e/ou individual.

No segundo estudo, em 1972, os autores perceberam que à medida que a campanha avançava, a atenção dos eleitores sobre os temas apresentados aumentava. E eles passaram a constituir um conjunto de informações mais ou menos comuns, o qual serviu como a base para a formação de uma atitude ou uma mudança de atitude diante dos candidatos apresentados. O processo de informação e de comunicação não é fechado, é contínuo. McCombs, segundo Hohlfeldt, denominou esse fluxo contínuo de informação de efeito enciclopédia e a mídia pode utilizar de procedimentos técnicos como box, suite para trabalhar essa informação. Outro ponto relevante do estudo, como mostra Hohlfeldt (1997, p.49) é que:

[...] a influência do agendamento por parte da mídia depende, efetivamente, do grau de exposição a que o receptor esteja exposto, mas, mais que isso, do tipo de mídia, do grau de relevância e interesse que este receptor venha a emprestar ao tema, a saliência que ele the reconhecer, sua necessidade de orientação ou sua falta de informação, ou, ainda, seu grau de incerteza, além dos diferentes níveis de comunicação interpessoal que desenvolver.

A agenda do receptor, por sua vez, também pode influenciar a agenda da mídia. O estudo mostrou, ainda, um interagendamento entre os diferentes tipos de mídia, estabelecendo, desta maneira, uma espécie de suíte sui generis, em que um tipo de mídia vai agendando o outro (HOHLFELDT, 1997).

Outra perspectiva é a do contra-agendamento que vê a relação entre mídia e sociedade de forma horizontal num movimento de mão dupla, de forma que a sociedade pauta a mídia promovendo a visibilidade de temas de relevância pública e a possibilidade de uma mobilidade social, via pressão do Estado. Após tornar-se pauta na mídia, o tema atinge uma audiência massiva, propiciando o debate público e legitimando o espaço no qual o mesmo ocorre. $\mathrm{O}$ contra-agendamento permite que certos temas descartados pela mídia hegemônica sejam atrativos e passíveis de integrar o discurso midiático (ROSSY, 2007).

O contra-agendamento compreende um conjunto de atuações que passam estrategicamente pela publicação de conteúdos na mídia e depende, para seu êxito, da forma como o tema-objeto-de-advocacia foi tratado pela mídia, tanto em termos de espaço, quanto em termos de sentido produzido. Pode-se então afirmar que o contraagendamento de um tema pode ser parte de uma mobilização social ou parte de um plano de enfrentamento de um problema, corporativo ou coletivo (SILVA, 2005 apud ROSSY, 2007, p.2). 


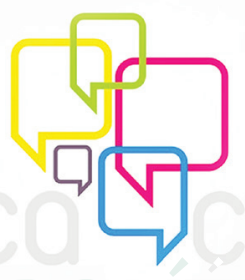

ação mididiática

N. 6 | Ano 2013

Universidade Federal do Paraná | Programa de Pós-Graduação em Comunicação

A internet como plataforma móvel possibilita o fluxo democrático das informações na sua produção e acesso, propiciando à sociedade inserir-se como co-partícipe no debate público de questões voltadas ao interesse público.

O "Mídia Ninja" 5 (Narrativas Independentes, Jornalismo e Ação) é uma mídia alternativa que surgiu em $2013^{6}$, a partir de movimento coletivo "Fora do Eixo", porém, sobressaiu durante o movimento "Vem Pra Rua". O Ninja acompanhou os acontecimentos, numa linha de ação de contra-agendamento, diante da cobertura formal da grande mídia, apresentando-se como espaço alternativo.

[...] o Mídia Ninja é bem-vindo e pode revolucionar o jornalismo brasileiro. Além de alternativo, o grupo tem pautado a grande imprensa, o que é um fenômeno notável. Para ele, é preciso avançar na discussão da interseção entre o jornalismo feito com base em ativismo político, social e cultural e o papel de mediador do profissional de imprensa. "Eu acompanho, fico acordado até duas, três horas da manhã com a Mídia Ninja, conheço todos eles da rede social e eu acho que é um fenômeno que veio para ficar e vai contagiar a grande imprensa", avaliou?

Para compreender a identidade dos jovens e adolescentes, a partir da comunicação, fazse necessário aproximação aos desafios criados pelo mundo globalizado em que, cada vez mais, a cultura da convergência oportuniza a configuração do conhecimento colaborativo, muitas das vezes, compartilhado através da apropriação dos jovens das mídias comunicacionais, principalmente, a Internet e o uso dos celulares, também considerados como 'dispositivos móveis'.

[...] a metáfora da rede, assim, oferece um modo interessante de compreender fenômenos contemporâneos da comunicação mediada pelo computador, que, sem dúvidas, complexificou em larga escala os fluxos comunicativos de nossa sociedade contemporânea. (RECUERO, 2009, p. 164)

Compreender o impacto das mídias comunicacionais, na configuração das redes

5 Disponível em: https://www.facebook.com/midiaNINJA?fref=ts Entrou no Facebook em: 27 mar. 2013.

6 “O Mídia Ninja foi fundado oficialmente há quatro meses, no Fórum Mundial de Mídia realizado na Tunísia. O grupo é ligado ao Circuito Fora do Eixo, uma rede de produtores culturais. Na internet, circulam acusações de que o grupo receberia verbas do PT". DINIZ, L. O jornalismo em tempo real da mídia ninja. Observatório da Imprensa. 01/08/2013, Ed. 757. Disponível em: http://www.observatoriodaimprensa.com.br/news/view/o_jornalismo_em tempo_real_da_midia_ninja Acesso em: 06 ago. 2013.

7 Nas palavras de Leonel de Aguiar, doutor em Comunicação e Cultura pela UFRJ, professor e coordenador do curso de Comunicação social da PUC-Rio. DINIZ, L. O jornalismo em tempo real da mídia ninja Observatório da Imprensa. 01/08/2013, Ed. 757. Disponível em: http://www.observatoriodaimprensa.com.br/news/view/o_jornalismo_em tempo real_da_midia_ninja Acesso em: 06 ago. 2013. 

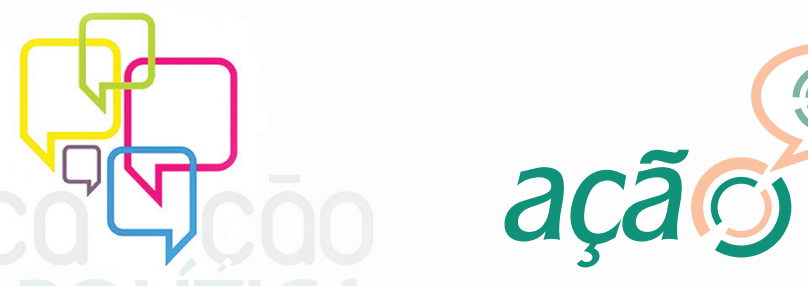

Estudos em Comunicação, Sociedade e Cultura

N. 6 | Ano 2013

Universidade Federal do Paraná | Programa de Pós-Graduação em Comunicação

sociais digitais junto aos adolescentes e jovens, como alternativas de relacionamento, socialização e compartilhamento de opiniões, é um desafio que merece investigação e mobiliza essa discussão teórica. A interação da Internet nos celulares oportuniza, também, apropriação simultânea dos recursos de mobilidade e acesso às informações.

A rede social digital (RSD) como Facebook é construída a partir do perfil de pessoas que se inter-relacionam com outras, a partir de preferências, dicas, textos, entre outros, compartilhados na "linha do tempo" de cada pessoa interatuante. A vida off-line e a vida online se entrecruzam para consolidar relacionamentos nessas RSDs. Quanto maior número de conexões, na rede de compartilhamento, maior visibilidade haverá. Por outro lado, os laços sociais, a partir dos laços relacionais, mostram a interação oportunizada pelas redes sociais digitais. Recuero (2009) se refere ao "capital social" como elemento indicativo da qualidade das conexões nas RSDs, "um valor constituído a partir das interações entre os atores sociais" (RECUERO, 2009, p. 45). Seguindo essa linha de pensamento, questionamse quais as formas de relacionamento que os jovens mantêm, a partir das comunidades em que eles se inserem? Se, por um lado, cada integrante da rede pertence a uma comunidade, por outro, qual a identidade que o jovem oportuniza aos outros integrantes dessa RSD? Afinal, qual é o "capital social” que está em jogo nas comunidades em que os jovens se inserem? Recuero considera o "capital social" "como um conjunto de recursos de um determinado grupo [...] que pode ser usufruído por todos os membros do grupo, ainda que individualmente, e que está baseado na reciprocidade [...]" (RECUERO, 2009, p.50). Essa inter-relação oportunizada pelas RSDs pode ultrapassar do campo virtual ao mundo material? Quais seriam os elementos que favoreceriam esse deslocamento, como aconteceu com o movimento "Vem pra Rua"? É necessário reflexão no sentido de compreender que a insatisfação dos jovens em relação não somente ao aumento do transporte coletivo de vinte centavos, isso foi à ponta do iceberg, contudo, de uma insatisfação relevante em termos da corrupção nacional, da distribuição de renda e favoritismos políticos.

Para entender essa questão, aproximou-se, em primeiro lugar, de Recuero, quem reverbera a definição de capital social de Putnam, no sentido de referir-se "à conexão entre indivíduos - redes sociais e normas de reciprocidade e confiança que emergem dela" (PUTNAM apud RECUERO, 2009, p.45). Conceito esse, visceralmente ligado a relações recíprocas e confiança, a partir de associações voluntárias e de cooperação. Em segundo lugar, a definição de capital social de Bourdieu, sob a ótica de poder, conflito e pertencimento a uma classe social, ou seja: “... recursos atuais e potenciais, os quais estão conectados com a posse de uma rede durável, de relações de conhecimento e reconhecimento mais ou menos institucionalizadas..." (BOURDIEU apud RECUERO, 2009, p. 46). Explica-se, dessa forma, o pertencimento, conhecimento e reconhecimento mútuo do grupo, criando 


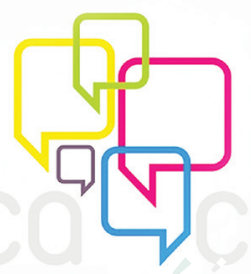

assim o capital simbólico do grupo, apesar de ser uma concepção considerada, muitas das vezes, como individualista, "a partir do momento que se foca na capacidade de um indivíduo contribuir e utilizar os recursos coletivos para seus próprios fins" (RECUERO, 2009, p. 49). Por fim, a definição de Coleman (COLEMAN Apud RECUERO, 2009, p. 48), a partir da qual o capital social "não está nos atores em si, mas em sua estrutura de relações [...]", dessa forma, priorizando-a.

O intercâmbio das informações, textos, fotografias e outros elementos conversacionais, de forma constante, através dos dispositivos midiáticos móveis, muitas das vezes no espaço público, a partir de tecnologia $w i-f$, disponibilizam significativa relevância, quando se inserem nas redes sociais digitais. A convergência gerada através do uso dos smartphones (os quais disponibilizam Internet nos celulares), os quais impactam não somente na agilidade no compartilhamento das informações como também reforçam a linha de pensamento de Castells, quando afirma que: "agora temos uma pele wireless sobreposta às práticas de nossas vidas, de tal forma que estamos em nós mesmos e em nossas redes ao mesmo tempo" (CASTELLS, 2008, p. 448). Essa singularidade oferece possibilidades ilimitadas na significação da comunicação contemporânea. Lemos (2007 apud FIRMINO, 2009, p.259-60) apresentou o conceito de hibridismo que os celulares adquiriram:

\footnotetext{
Pensar o celular como um 'Dispositivo Híbrido Móvel de Conexão Multirrede' (DHMCM) ajuda a expandir a compreensão material do aparelho e tirá-lo de uma analogia simplória com o telefone. A denominação de DHMCM permite defini-lo melhor e com mais precisão. O que chamamos de telefone celular é um Dispositivo (um artefato, uma tecnologia de comunicação); Híbrido, já que congrega funções de telefone, computador, máquina fotográfica, câmera de vídeo, processador de texto, GPS, entre outras; Móvel, isto é, portátil e conectado em mobilidade funcionando por redes sem fio digitais, ou seja, de Conexão; e Multirredes, já que pode empregar diversas redes, como: Bluetooth e infravermelho, para conexões de curto alcance entre outros dispositivos; celular, para as diversas possibilidades de troca de informações; internet (Wi-fi ou Wi-max) e redes de satélites para uso como dispositivos GPS.
}

No caso do "Mídia Ninja", sua existência é marcada na rede social digital, porém, com o traço de inserções de vídeos e outras informações jornalísticas, nos tempos da mobilidade. As transmissões são feitas em grande parte por celulares e dispositivos 4G, mais na base do improviso do que de um roteiro predefinido. Se a prática de transmitir atos públicos não é nova, a visibilidade que ela ganhou com o grupo surpreende, chegando a bater a marca dos 100 mil espectadores. Os ninjas divulgam seu conteúdo pelas redes sociais e têm uma resposta do público que supera em muito a interação vista em páginas de veículos da grande 


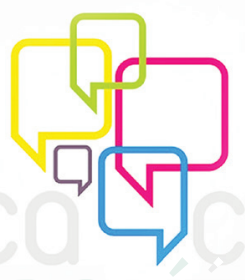

ação minidiática

N. 6 | Ano 2013

Universidade Federal do Paraná I Programa de Pós-Graduação em Comunicação

mídia brasileira. Eles já contam com mais de 120 mil curtidores no Facebook, em uma conta criada há cerca de quatro meses ${ }^{8}$.

Sendo assim, torna-se uma experiência significativa e relevante, em termos de jornalismo móvel. Destaque para o fato de configurar-se como mídia alternativa, sendo inserida numa rede social digital de ampla repercussão como Facebook.

Cada repórter-ninja tem um perfil de atuação, mas todos têm o mesmo objetivo: quebrar a narrativa uníssona da grande imprensa usando a própria mídia como arma. A cobertura engajada é a principal marca do grupo, que participa ativamente dos fatos que mostra. Após o confronto com a polícia, os repórteres-ninja Felipe Peçanha e Felipe Assis foram detidos no Rio sob a acusação de incitar a violência. Sem apuração e checagem de informações, ou abrindo espaço para que o outro lado se manifeste, o Mídia Ninja começa a chamar a atenção da grande imprensa. E se distancia do circuito alternativo para se converter em protagonista9.

As RSD e o dispositivo móvel, como o celular, oferece uma característica singular no caso "Mídia Ninja", no sentido de aliar essas duas alternativas de espaço digital e o compartilhamento de ideias, informações e opiniões. Contudo, o grupo ninja considera urgente a necessidade de implementar um site ou portal para imprimir marca editorial.

\begin{abstract}
A explosão repentina das ruas acabou adiando o processo de construção do site do coletivo. 'Estamos limitados na nossa capacidade jornalística por estarmos só no $\mathrm{Fa}$ cebook', observa Torturra. 'Tudo está mudando muito rápido pra que a ideia de site que vinha sendo discutida pudesse ser colocada no ar. Precisamos sair do Facebook para conseguir explorar melhor as possibilidades editoriais. Pensamos em algo como um portal que fosse também uma rede social', complementa ${ }^{10}$.
\end{abstract}

O jornalismo móvel é conceituado a partir da apropriação constante que os dispositivos integrados, na convergência digital, têm na produção jornalística (FIRMINO, 2009). Ou seja, o jornalismo móvel "pode ser definido como o uso de tecnologias móveis e conexões sem fio para o processo de apuração, edição e/ou transmissão de conteúdos do local do acontecimento" (FIRMINO, 2013, p.97).

8 MAZOTTE, N. Jornalistas independentes da mídia ninja ganham atenção. Observatório da Imprensa. Em 30/07/2013 na edição 757. Disponível em: http://www.observatoriodaimprensa.com.br/news/view/ed757 jornalistas independentes da_midia_ninja_ganham_atencao Acesso em: 06 ago. 2013.

9 DINIZ, L. O jornalismo em tempo real da mídia ninja. Observatório da Imprensa. 01/08/2013, Ed. 757. Disponível em: http://www.observatoriodaimprensa.com.br/news/view/o jornalismo em tempo real da midia ninja Acesso em: 06 ago. 2013.

10 MAZOTTE, N. Jornalistas independentes da mídia ninja ganham atenção. Observatório da Imprensa. Em 30/07/2013 na edição 757. Disponível em: http://www.observatoriodaimprensa.com.br/news/view/ed757 jornalistas independentes da midia ninja ganham atencao Acesso em: 06 ago. 2013. 


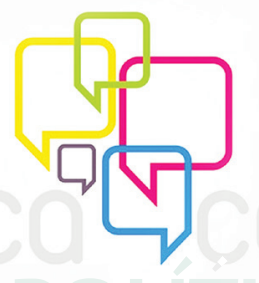

açãô midiática

N. 6 | Ano 2013

\title{
Universidade Federal do Paraná I Programa de Pós-Graduação em Comunicação
}

\begin{abstract}
'Mídia ninja' passou a simbolizar uma forma individual de colher e transmitir informações, notícia em estado bruto, sem passar pela cosmética da edição. Para alguns, mídia ninja é também um jornalismo ativista, militante, capaz de romper o conformismo dos meios tradicionais. Eles se consideram pós-jornalistas, mas há quem os classifique como pré-jornalistas... Pode ser visto como o "jornalismo-cidadão" sonhado a partir das novas tecnologias ou como "jornalismo marginal", herdeiro direto dos quatro séculos de inconformismo da imprensa histórica ${ }^{11}$.
\end{abstract}

O "Mídia Ninja" repercutiu na imprensa brasileira como marco da liberdade de expressão, assim como pela experimentação das mídias digitais no caso brasileiro, porém, não se sabe como será sua consolidação, num tempo futuro, já que manter-se no mercado editorial é uma meta desafiadora. Além disso, vários desdobramentos surgirão, no sentido de compreender os critérios editoriais propostos pelos ninjas, o qual será motivo de outras abordagens e pesquisas. No entanto, é relevante enfatizar que o caso ninja reforça as concretas possibilidades que o jornalismo móvel de fato tem, não somente como relatos de experiências no exterior e no campo das grandes mídias, mas também, como experiência midiática brasileira e de coletivos alternativos.

Esse emblemático caso ninja reforça a necessidade de reflexão em relação à formação do jornalista multimídia atual, como considera Firmino (2013, p.105):

[...] cremos que o jornalismo móvel se caracterizar como uma modalidade dentro do jornalismo com suas especificidades e com usos mais específicos por exigir dos repórteres um treinamento, habilidades especificas para lidar com dispositivos móveis e uma estratégia de atuação que potencialize o trabalho de produção em vez de acarretar consequências em termos de condições para apuração da notícia. Portanto, estamos nos referindo ao estabelecimento de uma lógica que considere um trabalho multitarefa de uma forma mais estratégica visando incremento da qualidade do produto, pela geração mais completa de formatos (áudio, vídeo, textos, imagens), mas que preserve os princípios de qualidade requeridos no processo jornalístico. Esse é o ponto nefrálgico da questão. (FIRMINO, 2013, p.105)

Sem dúvida, os tempos da convergência disponibilizam oportunidades de compartilhamento, instantaneidade e colaborativismo, na produção de conteúdo, no sentido de que os desafios, em termos da formação dos futuros jornalistas, implicam na atualização de competências e habilidades, em relação à nova configuração da realidade social, porém, sem deixar de lado a visão humanística e da cidadania do jornalismo como

11 DINES, A. Hora das mídias alternativas. Observatório da Imprensa na TV nº 694, Exibido em 30/7/2013. Disponível em: http://www.observatoriodaimprensa.com.br/news/view/o_jornalismo_em tempo_real_da_midia_ninja Acesso em: 06 ago. 2013. 


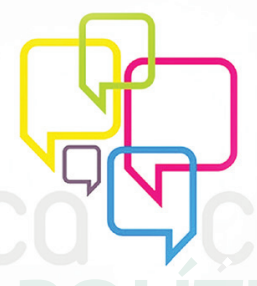

ação minidiática

N. 6 | Ano 2013

\section{Universidade Federal do Paraná I Programa de Pós-Graduação em Comunicação}

profissão. Talvez, nunca antes foi tão importante ressaltar que tanto mais importante que se adequar às mudanças técnicas, o mais relevante é apurar o senso de responsabilidade social que o jornalista tem como parte de sua essência e episteme.

\section{A força da imagem: potencialidades nas mídias digitais}

A exemplo da grande imprensa, que optou por abrir espaços significativos de suas páginas para fotos das manifestações dos jovens, a mídia alternativa também fez valer sua força como meio informativo, por meio das redes sociais e de forma muito mais livre e independente. A força de interconexão, proporcionada pela internet - facebook, twitter, blogs - aliado a dispositivos como celulares, tablets, laptops constituíram um ambiente propício para difundir a todos os cantos este protesto social, iniciado nos grandes centros urbanos, que tomou proporções jamais vistas na história do país.

Jornais como Folha de São Paulo, O Globo e revistas de circulação nacional também entraram na 'onda' e não se furtaram de colocar a público as diversas reivindicações do povo brasileiro. Veja, Istoé e Época durante semanas seguidas, em junho, evidenciaram este acontecimento nas capas, utilizando-se de fotos e ilustrações dramáticas. As redes sociais, mais livres da pressão do mercado, dos anunciantes e do próprio governo, contribuíram para divulgar os protestos, mas também para motivar a participação no movimento que ganhou dimensão nacional e internacional.

Os jovens conectados na rede mundial de computadores pularam de um site para outro, vistoriavam as informações vindas dos blogs e Facebook e se sentiram parte do movimento, porque compartilhavam das mesmas preocupações e reivindicações daqueles que estavam nas ruas. Isto seria um sinal de que as coisas estão mudando no Brasil e na área comunicativa.

Neste episódio, como já se viu aqui, o "Mídia Ninja" deu sua parcela de contribuição e muito destaque ao fotojornalismo. As fotos ajudaram a contar a história do que estava acontecendo no país. O texto, muitas vezes, complementava a fotografia, invertendo uma tendência histórica do papel da foto. As imagens disponibilizadas na página tinham valor e foram amplamente compartilhadas.

O "Mídia Ninja", fenômeno que alcançou evidência com o movimento das ruas, ao longo dos meses de junho e julho, caprichou em narrar os fatos por meio de imagens e textos curtos. Como observa Kobré (2011, p. 229) "histórias inteiras" podem ser contadas por meio de fotos. Às vezes estas histórias podem ser construídas em questões de minutos, semanas, anos. A fotorreportagem, ele explica, teve um crescimento significativo no mundo moderno, especialmente com o advento da Internet, período em que fotos, textos, notícias rompem todas as fronteiras geográficas. Hoje uma foto, uma série de fotografias, pode ser vista quase que em tempo real em todos os cantos do mundo. 


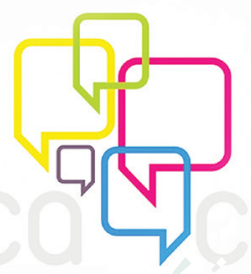

açãô I) midiática

N. 6 | Ano 2013

Universidade Federal do Paraná I Programa de Pós-Graduação em Comunicação

Para registrar esses acontecimentos recentes do Brasil, o "Mídia Ninja", lançou mão de inúmeras fotos envolvendo temas como o confronto entre manifestantes e a polícia, a ocupação de prédios públicos, as manifestações em frente ao congresso, os protestos nas ruas, praças e avenidas. Tudo isso retratado com rigor jornalístico e técnicas fotográficas que valorizam o primeiro plano, a composição, a luz, o movimento, as expressões, a indignação do povo. O trabalho fotojornalístico mostrou quando os manifestantes foram para frente do congresso, no mês de junho, reclamar contra descaso e a falta de atitude dos políticos (Figura 1).

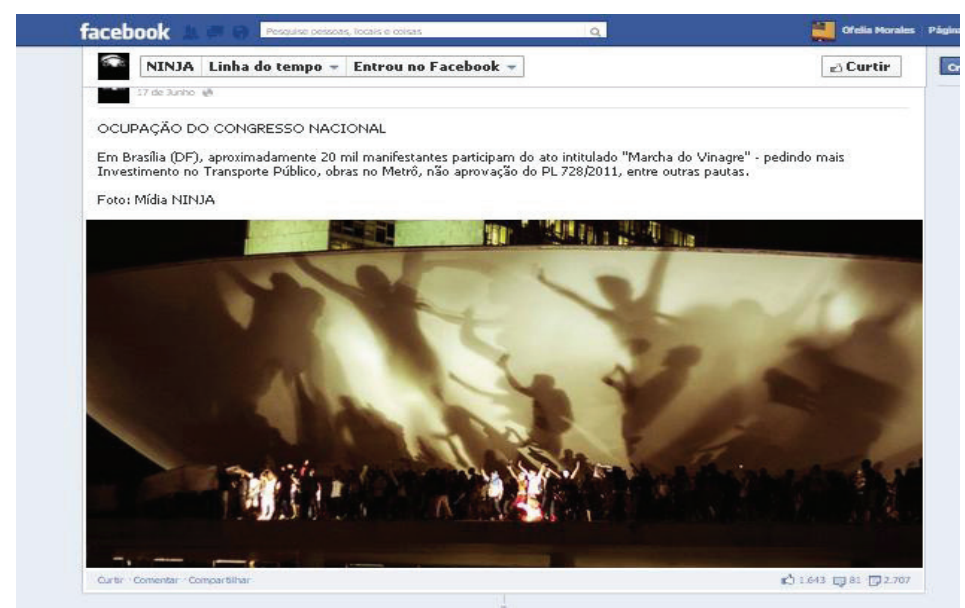

Figura 1 - Foto sobre as manifestações "Vem Pra Rua", em Brasília, no Facebook do "Mídia Ninja", em junho de $2013^{12}$.

A foto faz remissão ao Mito da Caverna ${ }^{13}$ de Platão, por suas sombras na parede do prédio, em uma época em que as imagens evidenciavam ilusão daqueles que viviam acorrentados na caverna ${ }^{14}$.

Mas ao mesmo tempo se trata de uma foto moderna, colorida, digital. Este registro estabelece uma ponte entre as primeiras manifestações imagéticas, da alegoria da caverna, e as imagens modernas, que procuram revelar, por meio de representações, a realidade do mundo (CHAUI, 1999, p.41). Vivemos hoje um novo momento, como aponta Sontag (2004, p. 13), um período de proliferação de imagens. Elas, "modificam e ampliam nossas ideias sobre o que vale a pena olhar", o que interessa, o que desperta nossas emoções, sentimentos. Como bem observa Barthes (1982), as fotografias comportam mensagens e sentidos. Ele fala do caráter denotativo

12 Disponível em: https://www.facebook.com/midiaNINJA Acesso em: 06 ago.2013.

13 PLATÃO. A República. São Paulo: Editora Nova Cultural Ltda., 1997. Trad. Enrico Corvisieri.

14 O que é a caverna? O mundo em que vivemos. Que são as sombras das estatuetas? As coisas materiais e sensoriais que percebemos. Quem é o prisioneiro que se liberta e sai da caverna? O filósofo. O que é a luz exterior do sol? A luz da verdade. O que é o mundo exterior? O mundo das ideias verdadeiras ou da verdadeira realidade. Qual o instrumento que liberta o filósofo e com o qual ele deseja libertar os outros prisioneiros? A dialética [...] (CHAUI, 1999, p.41). 


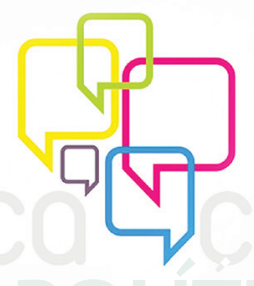

açãô I) midiática

N. 6 | Ano 2013

Universidade Federal do Paraná | Programa de Pós-Graduação em Comunicação

e conotativo de uma imagem. O significado do que se vê, depende de nossa compreensão, do contexto e também do sentido proposto pelo fotógrafo, pelo veículo e sua linha editorial. Uma mesma foto, um mesmo acontecimento pode ser mostrado de diversas formas e ter múltiplos sentidos, dependendo principalmente do propósito do fotógrafo, das suas intenções, dos critérios de sua empresa. Por exemplo, no movimento "Vem Pra Rua", a mídia tradicional explorou muito os atos de vandalismo, procurando descaracterizar o que estava acontecendo. Já "Mídia Ninja" teve uma outra postura, mais compromissada com o movimento.

Às vezes o que ela revela ultrapassa o sentido literal, requer interpretação. Por outro lado, a fotografia é memória. Os registros feitos pela mídia impressa e digital dos fatos vão marcar nossa história. Boris Kossoy (2001, p. 156) explica que a fotografia é uma fonte inesgotável de informação e emoção. É, nesse sentido, um documento que retém a imagem fugidia de um instante da vida que flui ininterruptamente.

Ao longo de sua trajetória, a imagem fotográfica (SOUZA; JASPER; KALIBERDA, 2013, p. 3) foi "se firmando no imaginário popular como prova definitiva de que algo aconteceu e testemunho da verdade do fato, uma maneira credível de se dizer que nada foi alterado no acontecimento ao ser fotografado". Segundo Susan Sontag (2004, p.22), "fotografar é, em essência, um ato de não intervenção [...]".

E os fotojornalistas que postaram nas páginas do "Mídia Ninja" angularam e fizeram composições marcantes desse movimento nacional que ocupou ruas, praças, avenidas e prédios públicos. As fotos publicadas em jornais, revistas e na internet registram milhares de manifestantes nas ruas e isso serviu, também, para motivar a participação. Os jovens se sentiram envolvidos pelos gritos da rua e marcaram sua presença no evento histórico. A própria mídia divulgava diariamente o crescimento do movimento em todas as capitais e cidades brasileiras.

As fotos publicadas ao longo dos meses de junho e julho na página do "Mídia Ninja" procuravam retratar o movimento da rua. Pela beleza plástica das imagens, a dramaticidade das cenas, os efeitos de iluminação, os destaques em primeiro plano, os atos de repressão militar, a revolta social, - publicadas também em outros meios - ajudaram a moldar a cena social e o contexto vivido.

A equipe editorial do "Mídia Ninja" soube aproveitar a força das imagens para marcar a sua história neste episódio e até para se diferenciar no meio jornalístico pela postura e tratamento dado aos acontecimentos (Figuras 2 e 3 ). 


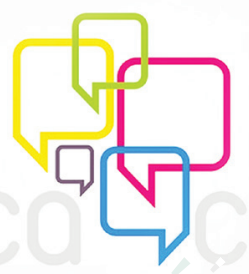

açãô I) Midiática

N. 6 | Ano 2013

\section{Universidade Federal do Paraná | Programa de Pós-Graduação em Comunicação}

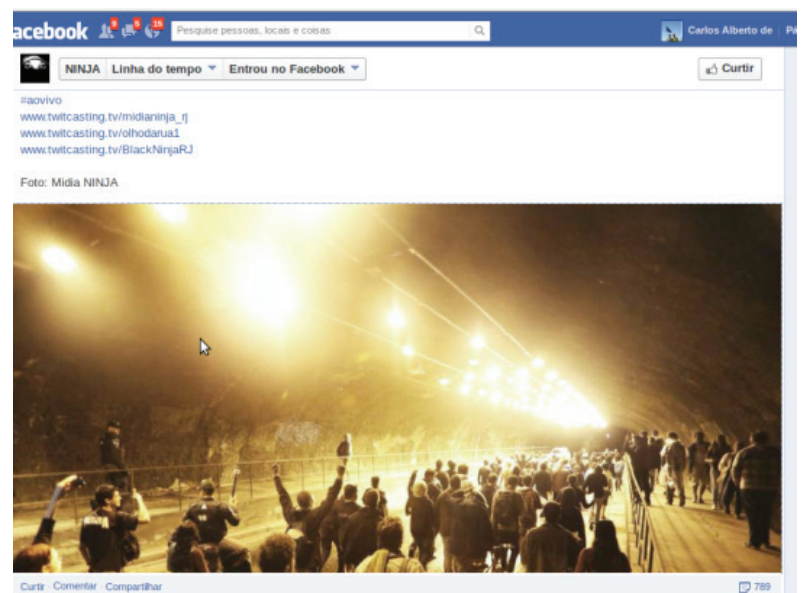

Figura 2 - Foto das manifestações do "Vem Pra Rua", no Facebook, do "Mídia Ninja, em junho de 2013 ".

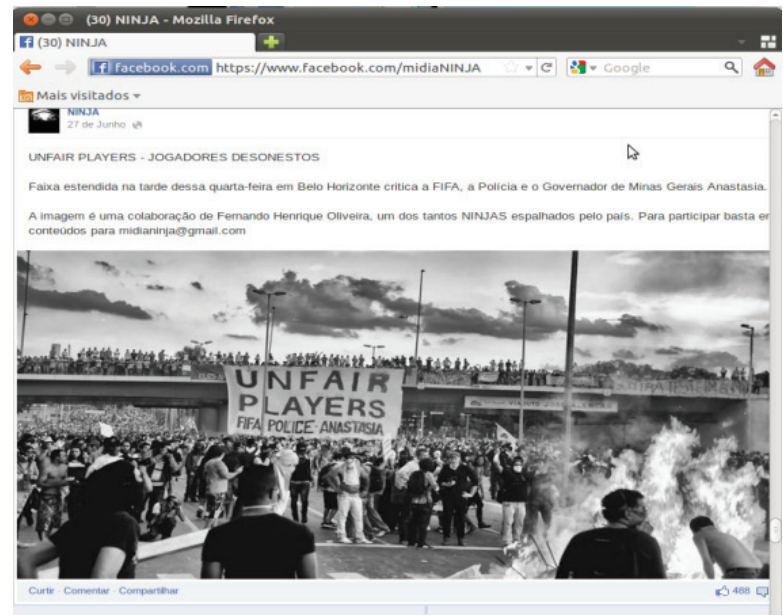

Figura 3 - Foto das manifestações do "Vem Pra Rua", em Belo Horizonte, no Facebook, do "Mídia Ninja, em junho de $2013^{16}$.

Além de dar destaques a fotos bem enquadradas e a composições marcantes, o site se utilizou também de fotos em PB que, além de sua característica histórica, contribuíram para dramatizar determinadas cenas. As fotos de todo este acontecimento são importantes para marcar este momento brasileiro às novas gerações, nestes dias em que o povo se levantou para a moralização do país.

\section{Algumas Considerações}

A pesquisa exige um processo de indagação científica para criar conhecimento novo. Conforme Lopes (2004, p.30), “toda pesquisa é uma verdadeira 'aventura metodológica', onde

15 Disponível em: https://www.facebook.com/midiaNINJA Acesso em: 06 ago.2013.

16 Disponível em: https://www.facebook.com/midiaNINJA Acesso em: 06 ago.2013. 


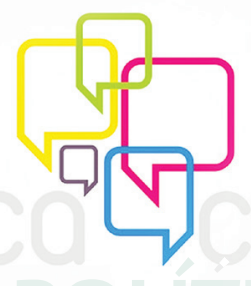

ação) İ Imidiática

N. 6 | Ano 2013

Universidade Federal do Paraná | Programa de Pós-Graduação em Comunicação

há necessidade de exploração, criatividade e de rigor." Nessa linha de pensamento, o estudo pretendeu aprofundar a compreensão no campo da comunicação, mais especificamente, do jornalismo, com o objetivo de revelar a representação dos jovens na mídia, e o seu relacionamento de apropriação, a partir das mídias digitais.

Objetivou-se abordar, de forma inicial, o relacionamento e as potencialidades que as redes sociais digitais e o jornalismo móvel oportunizam, no mundo atual, de forma simultânea. Tenta compreender como esses dispositivos móveis impactam no cotidiano dos jovens como meios de educação informal.

Os impactos dessa pesquisa são variados. Em primeiro lugar, a percepção do jornalismo móvel como pontapé inicial de novos formatos jornalísticos, especificamente, brasileiros. Em segundo lugar, destacam-se as redes sociais digitais e o seu impacto nos relacionamentos interpessoais, focalizados principalmente nos jovens. Por outro lado, a pesquisa tem possibilidades de ser ampliada a análises futuras, a partir de outros estudos de caso, relacionados aos jovens como sujeitos de expressão nas mídias digitais.

A atenção neste estudo foi dada à cobertura jornalística do Facebook "Mídia Ninja", que assumiu importante papel na exposição da crise sem precedente no Brasil, que mobilizou milhares de jovens e famílias a partir da internet e do dispositivo móvel. Eles assumiram a condição de sujeito no processo político e social por determinado tempo. A pesquisa exploratória, que envolveu estudo de caso e análise da cobertura do "Mídia Ninja", mostra que as redes de comunicação não tradicionais estão contribuindo para mudar o cenário da comunicação no país e, ao mesmo tempo, criando novas condições de interação e reação social. O evento, "Vem pra Rua", foi sintomático, pois revelou formas diferentes de ação que acabou tendo repercussão em nível nacional e internacional. O Brasil, neste caso específico, deu exemplo ao mundo de novas possibilidades de mobilização social.

\section{Referências}

ANDRADE, M.M.de. Introdução à metodologia do trabalho científico. São Paulo: Atlas, 2005.

BARTHES, R. A mensagem fotográfica. In: COSTA LIMA, L. (org.). Teoria da Cultura de Massa. Rio de Janeiro: Paz e Terra, 1982.

CASTELLS, M. A era da informação: economia, sociedade e cultura. Volume I. A Sociedade em Rede. Lisboa: Fundação Calouste Gulbenkian, 2002.

CASTELLS, M. Afterword. In: KATZ, J. E. Handbook of Mobile Communication Studies. Cambridge: MIT Press, 2008. p. 447-451. 

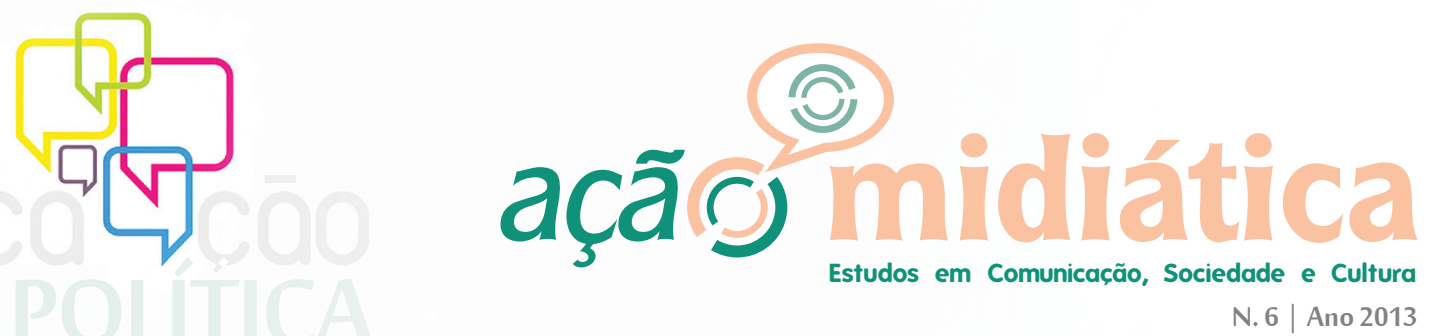

Universidade Federal do Paraná I Programa de Pós-Graduação em Comunicação

CHAUI, M. Convite à filosofia. São Paulo: Editora Ática, 1999.

FIRMINO DA SILVA, F. Moblogs e microblogs: jornalismo e mobilidade. In: AMARAL, A.; RECUERO, R.; MONTARDO, S. (Orgs.). Blogs.com: estudos sobre blogs e comunicação. São Paulo: Momento Editorial, 2009. p. 257-274.

FIRMINO DA SILVA, F. Repórteres em campo com tecnologias móveis conectadas. In: BARBOSA, S.; MIELNICZUK, L. (Org.). Jornalismo e Tecnologias Móveis. Covilhã: UBI / LabCom, 2013.

HOHLFELDT, A. Os estudos sobre a hipótese de agendamento. Revista FAMECOS. FAMECOS, Porto Alegre, No. 7, nov., 1997.

KOBRÉ, K. Fotojornalismo, uma abordagem profissional. Rio de Janeiro: Elsevier, 2011. KOSSOY, B. Fotografia e história. São Paulo: Ateliê Editorial, 2001.

LOPES, M.I.V.de. Pesquisa de comunicação. Revista Brasileira de Ciências da Comunicação. INTERCOM, São Paulo: No.1, jan./jul., Vol. XXVII, 2004.

RECUERO, R. Redes sociais na internet. Porto Alegre: Sulina, 2009.

RODRIGUES, R.M. Pesquisa acadêmica. São Paulo: Atlas, 2007.

ROSSY, E. Contra-agendamento: o Terceiro Setor pautando a mídia. (2007). Disponível em: $<$ www.fafich.ufmg.br> Acesso em: 01 ago. 2013.

SANTAELLA, L. Comunicação e pesquisa. São Paulo: Hacker, 2001.

SONTAG, S. Sobre fotografia. São Paulo: Cia das Letras, 2004.

SOUZA, C.A. de; JASPER, A.; KALIBERDA, A. História da fotografia e do fotojornalismo em Ponta Grossa: por um projeto de resgate. In. $9^{\circ}$. Encontro Nacional de História da Mídia. Ouro Preto, 30 maio a 1 de junho 2013. 